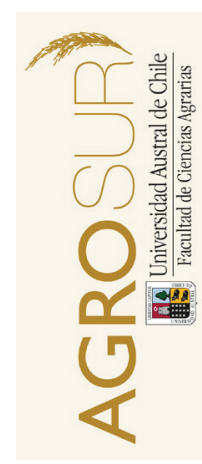

\title{
Los nuevos desafíos de la revista Agro Sur
}

\author{
The new challenges of Agro Sur
}

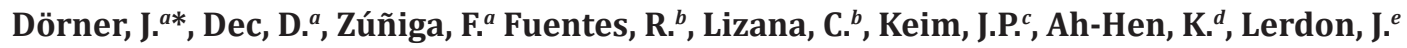

${ }^{a}$ Instituto de Ingeniería Agraria y Suelos, ${ }^{b}$ Instituto de Producción y Sanidad Vegetal, ${ }^{c}$ Instituto de Producción Animal, ${ }^{d}$ Instituto de Ciencia y Tecnología de los Alimentos, ${ }^{e}$ Instituto de Economía Agraria, Facultad de Ciencias Agrarias, Universidad Austral de Chile. Valdivia, Chile. *Autor de correspondencia: josedorner@uach.cl

E D I T O R I A L

To project ourselves in time, we must acknowledge where we came from and make a critical and constructive analysis of our current situation. In this context, since its creation in 1973 the journal Agro Sur has made a significant contribution to the development of agricultural knowledge in Chile and Latin America.

After objectively analizing the current scientific journals in general, and the situation of Agro Sur in particular, the Editorial Committee, with the support of the Faculty of Agricultural Sciences, have taken up the challenge to renew Agro Sur by giving it a new impetus to position and project it as a major journal within its scope. This renovation has involved a variety of measures, including: i) a critical analysis of its current situation, ii) a redefinition and broadening of the editorial line, iii) reviewing and speeding up peer review procedures and iv) improving the aesthetic of the journal and the access to it, among others. We hope these changes will serve to consolidate Agro Sur as the journal of choice for experienced professionals, young professionals and emerging scientists who contribute to the development of knowledge related to the agri-food chain.

We at Agro Sur have decided to continue to provide an important scientific and critical contribution for the development of the different areas associated with the agri-food chain, without neglecting the Efficient Use of Natural Resources, the Rural Development and Food Sovereignty. The renewed editorial line of Agro Sur allows for different types of contributions, including Original Research Articles, Case Studies, Technical Notes, Reviews and Viewpoints, which after being subjected to an efficient peer review process may be published as open access articles, with the hope that they will contribute to the knowledge and development of the agri-food chain in the Southern Cone.

\section{EDITORIAL}

Para proyectarnos en el tiempo tenemos que conocer de donde venimos y hacer un análisis crítico-constructivo de nuestra situación actual. En ese contexto, la revista Agro Sur desde su creación en el año 1973 ha hecho un aporte importante al desarrollo del conocimiento agropecuario en Chile y Latinoamérica.

Luego de un análisis objetivo de la evolución de las actuales revistas científicas en general, y de la situación de la revista Agro Sur, en particular, es que como Comité Editorial, con el apoyo de la Facultad de Ciencias Agrarias, hemos tomado el desafío de renovar Agro Sur otorgándole un nuevo impulso que permita posicionarla y proyectarla como una revista importante en su área. Esta renovación ha implicado diversas acciones, entre las que se cuentan: i) el análisis crítico de la situación actual, ii) una redefinición y ampliación de la línea editorial, iii) la revisión y agilización de los procedimientos de evaluación de pares y iv) el mejoramiento de la proyección estética y de acceso a la revista, entre otras. Con estos cambios esperamos consolidar Agro Sur como una alternativa de publicación para profesionales de larga trayectoria así como para jóvenes profesionales y científicos emergentes que generan conocimiento para el desarrollo de la Cadena Agroalimentaria.

De acuerdo a lo anterior, es que como revista Agro Sur nos hemos planteado, seguir siendo un aporte científico y crítico importante para el desarrollo de las diversas áreas asociadas a la Cadena Agroalimentaria, sin dejar de lado el Uso Eficiente de los Recursos Naturales, el Desarrollo Rural y la Soberanía Alimentaría. La renovada línea editorial de la revista Agro Sur permite hacer diversos tipos de aportes, desde Artículos de Investigación Original, Estudios de Casos, Notas Técnicas, Revisiones hasta Puntos de Vista, que luego de pasar por un proceso eficiente de revisión de pares, son publicados en un sistema de libre acceso, que esperamos contribuyan al conocimiento y desarrollo de la Cadena Agroalimentaria del Cono Sur. 
